\title{
TEKNIK PENANAMAN JAJAR LEGOWO UNTUK PENINGKATAN PRODUKTIVITAS PADI SAWAH DI JAWA TENGAH
}

\author{
Octavia Rizky Prasetyo ${ }^{1}$, Kadir $^{2}$ \\ ${ }^{1,2}$ Badan Pusat Statistik \\ ${ }^{1}$ octavia.rizky@bps.go.id; ${ }^{2}$ kadirsst@bps.go.id
}

\begin{abstract}
This research is aimed to analyse the distribution of a cultivation technique of wetland paddy so-called "Jajar Legowo" in Central Java Province as well as its impact on paddy productivity. We made use of the Results of the 2017 Cost Structure of Food Crops Cultivation Survey carried out by Statistics Indonesia (BPS). A spatial analysis and an estimation of Ordinary Least Square (OLS) regression model was used to achieve aims. Our results pointed out that the wetland paddy households implementing the technique only made up about 32.05 per cent of the total number of wetland paddy households in Central Java. They were concentrated in some municipalities, i.e., Prubalingga, Banjarnegara, Grobogan, Kudus, Demak, Temanggung and Kendal. Meanwhile, the OLS estimations showed that the technique has a significant impact in boosting productivity up to 16 per cent compared to other cultivation techniques. Therefore, it could be a key measure in increasing rice production in Central Java. Moreover, our findings also pointed out that other measures such as enhancing the capacity of farmers, the use of highquality seed and mechanisation and improving the access on financial resources also have a pivotal role in improving the productivity of paddy in the province.
\end{abstract}

Keyword: productivity, jajar legowo, OLS regression.

Abstraksi. Penelitian ini bertujuan menganalisis sebaran implementasi sistem tanam jajar logowo dalam budidaya tanaman padi sawah di Provinsi Jawa Tengah serta dampaknya terhadap peningkatan produktivitas tanaman padi. Data yang digunakan adalah hasil Survei Struktur Ongkos Usaha Tanaman Pangan 2017 yang dilaksanakan oleh BPS. Analisis spasial dan estimasi model regresi OLS digunakan untuk mencapai tujuan. Hasil penelitian menunjukkan meski sistem tanam jajar legowo menjanjikan produktivitas yang lebih tinggi, proporsi rumah tangga padi sawah yang menerapkan teknik ini masih relatif kecil, yakni hanya sebesar 32,05 persen dari total rumah tangga usaha tanaman padi sawah. Kabupaten/kota dengan tingkat implementasi sistem tanam Jajar Legowo relatif tinggi terkonsentrasi di Kabupaten Prubalingga, Banjarnegara, Grobogan, Kudus, Demak, Temanggung, dan Kendal. Sementara itu, hasil estimasi regresi OLS mengkonfirmasi bahwa sistem tanam jajar legowo berdampak signifikan terhadap peningkatan produktivitas sampai dengan 16 persen dibandingkan dengan teknik penanaman lainnya. Karena itu, meningkatkan partisipasi petani dalam implementasi sistem tanam ini dapat menjadi salah satu upaya yang dapat ditempuh untuk meningkatkan produksi padi secara signfikan di Provinsi Jawa Tengah. Selain itu, meningkatkan kapasitas petani, penggunaan benih unggul dan alsintan, dan meningkatkan akses petani untuk mendapatkan pinjaman modal dari bank juga berdampak signifikan dalam meningkatkan produktivitas tanaman padi sawah yang dibudidayakan oleh petani.

Kata kunci: produktivitas, jajar legowo, regresi OLS 


\section{PENDAHULUAN}

Padi merupakan komoditas yang sangat strategis di Indonesia. Dari tahun ke tahun, permintaan terhadap beras, yang merupakan produk olahan padi, akan terus meningkat seiring dengan peningkatan pertumbuhan penduduk mengingat sebagian besar masyarakat Indonesia masih mengkonsumsi beras sebagai makanan pokok. Hal ini mendorong pemerintah untuk terus melakukan berbagai upaya dalam meningkatkan produksi padi nasional, antara lain dengan perluasan areal tanam dan peningkatan produktivitas.

Masifnya konversi lahan pertanian menjadi lahan non-pertanian, seperti untuk lahan industri, perumahan dan infrastruktur, menyebabkan upaya perluasan areal tanam, khususnya lahan sawah, menjadi sulit untuk diterapkan. Berdasarkan Keputusan Menteri ATR/Kepala BPN-RI No.399/Kep23.3/X/2018 tanggal 8 Oktober 2018, disampaikan bahwa luas lahan baku sawah nasional tahun 2018 sebesar 7.105.145 hektar. Dengan kata lain, luas lahan baku sawah mengalami penurunan sekitar 8 persen jika dibandingkan dengan luasan tahun 2013 menurut SK Kepala BPN RI yang sebesar 7.750.999 hektar. Di samping itu, menurut Sembiring (2007) keberhasilan peningkatan produksi padi lebih banyak disumbang oleh peningkatan produktivitas dibandingkan dengan peningkatan luas panen. Peningkatan produktivitas memberikan kontribusi sekitar $56,1 \%$ terhadap peningkatan produksi padi, sedangkan peningkatan luas panen dan interaksi keduanya memberikan kontribusi masing-masing hanya $26,3 \%$ dan $17,5 \%$. Kondisi tersebut menunjukkan bahwa peningkatan produktivitas dengan menggunakan inovasi teknologi menjadi pilihan yang lebih menjanjikan dalam upaya peningkatan produksi padi.

Jawa Tengah merupakan salah satu provinsi sentra produksi padi di Indonesia. Berdasarkan data Badan Pusat Statistik (BPS), Jawa Tengah menjadi penyumbang produksi padi tertinggi ketiga dengan produksi diperkirakan mencapai 9,51 juta ton GKG pada tahun 2018. Angka ini mencakup sekitar 16,85 persen dari total produksi padi nasional. Tentunya hal ini tidak lepas dari beragam upaya peningkatan produktivitas yang telah dilakukan oleh pemerintah Jawa Tengah.

Salah satu teknologi budidaya padi yang menjadi unggulan dalam mendukung peningkatan produktivitas padi secara nasional, termasuk di Jawa Tengah, yaitu sistem tanam jajar legowo. Pada prinsipnya, sistem tanam jajar legowo adalah upaya dalam meningkatkan populasi tanaman padi dengan cara mengatur jarak tanam. Sistem tanam ini juga memanipulasi tata letak tanaman, sehingga rumpun tanaman sebagian besar menjadi tanaman pinggir (Ikhwani, dkk, 2013). Dengan sistem tanam jajar legowo maka tanaman padi pada barisan tanaman terluar memperoleh ruang tumbuh yang lebih longgar sekaligus sirkulasi udara dan pemanfaatan sinar matahari lebih baik untuk pertanaman. Selain itu, upaya penanggulangan gulma dan pemupukan 
dapat dilakukan dengan lebih mudah (Dirjen Tanaman Pangan, 2016).

Berdasarkan hasil Survei Struktur Ongkos Usaha Tani (SOUT) tahun 2017, rumah tangga petani padi sawah di Jawa Tengah sebagian besar masih menggunakan sistem tanam tegel yaitu sebesar 61,97 persen, sedangkan yang menerapkan sistem tanam jajar legowo hanya sebesar 32,05 persen. Padahal, rata-rata produktivitas padi sawah yang dihasilkan dengan menggunakan teknik budidaya jajar legowo lebih tinggi jika dibandingkan rata-rata produktivitas padi sawah yang menggunakan sistem tegel. Produktivitas padi sawah yang dihasilkan dengan sistem tanam jajar legowo mencapai 54,48 ku/ha. Sementara itu, produktivitas padi sawah yang ditanam dengan sistem tegel hanya mencapai $47,68 \mathrm{ku} / \mathrm{ha}$.

\section{Gambar 1. Perbandingan Rata-rata Produktivitas Padi Sawah di Jawa Tengah menurut Teknik Budidaya, 2017}

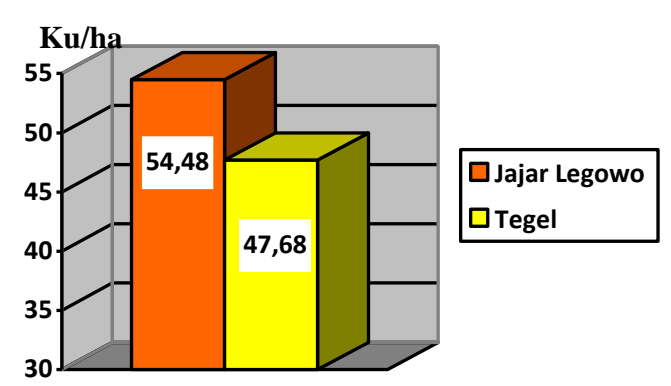

Sumber: Data Survei Struktur Ongkos Usaha Tani (SOUT) Tanaman Pangan 2017, BPS (diolah penulis)

Sejumlah penelitian mengenai dampak implementasi jajar legowo terhadap peningkatan produktivitas padi di Indonesia memperlihatkan bahwa sistem tanaman ini dapat menghasilkan produktivitas yang lebih tinggi dibanding sistem tanam konvensional, misalnya dengan sistem tanam tegel. Penelitian mengenai dampak sistem tanam jajar legowo terhadap produktivitas umumnya merupakan studi kasus dalam bentuk rancangan percobaan dengan cakupan penelitian yang sangat terbatas. Witjaksono (2018) melakukan kajian sistem tanam jajar legowo untuk varietas Inpari 30 dan 15 di Kabupaten Konawe, Sulawesi Tenggara. Hasil kajian menunjukkan bahwa sistem jajar legowo mampu meningkatkan produksi padi sebesar 16,44 persen dibandingkan dengan sistem konvensional. Susilastuti, dkk (2018) melakukan percobaan untuk mengetahui dampak dari pola tanam jajar legowo terhadap hasil panen varietas padi Ciherang di Desa Bojongmangu, Bekasi. Mereka menemukan bahwa sistem tanam jajar legowo 2:1 memberikan hasil produktivitas tertinggi jika dibandingkan sistem tanam lainnya.

Tujuan utama dari penelitian ini adalah menganalisis sebaran implementasi sistem tanam jajar legowo untuk komoditas padi sawah di Provinsi Jawa Tengah serta menganalisis pengaruh sistem tanam jajar legowo terhadap produktivitas tanaman padi. Untuk memperkaya analisis, dalam penelitian ini dampak variabel-variabel lain yang mempengaruhi produktivitas, seperti demografi petani dan karakteristik budidaya tanaman padi, juga dianalisis. Sejauh pengetahuan kami, studi mengenai dampak sistem tanam jajar legowo terhadap produktivitas tanaman padi berdasarkan hasil implementasi riil lapangan di Provinsi Jawa Tengah, 
khususnya yang memanfaatkan data mikro hasil survei dengan level estimasi hingga level provinsi, masih sangat terbatas. Karena itu, penelitian ini diharapkan dapat memperkaya kajian mengenai dampak implementasi sistem tanam jajar legowo di lapangan terhadap peningkatan produksi padi sawah, khususnya di Provinsi Jawa Tengah. Selain itu, hasil penelitian ini diharapkan dapat memberikan kontribusi bagi pemerintah Provinsi Jawa Tengah sebagai bahan evaluasi kebijakan dalam hal peningkatan produktivitas tanaman padi sawah melalui implementasi sistem tanam jajar legowo.

\section{METODE PENELITIAN}

\section{Sumber Data dan Variabel Operasional}

Penelitian ini menganalisis data mikro hasil Survei Struktur Ongkos Usaha Tani (SOUT) Tanaman Pangan 2017 untuk Provinsi Jawa Tengah. SOUT merupakan survei yang dirancang untuk memotret struktur ongkos usaha tanaman pangan termasuk padi. Selain informasi terkait struktur ongkos, survei ini juga mengumpulkan informasi mengenai produktivitas, profil petani, dan karakteristik budidaya. Jumlah sampel rumah tangga usaha budidaya tanaman padi sawah yang dianalisis dalam penelitian ini sebanyak 11.498 rumah tangga. Variabel yang digunakan dalam penelitian ini beserta penjelasan ringkasnya disajikan pada Tabel 1 .

Dalam menganalisis pengaruh sistem tanam jajar legowo terhadap produktivitas, penulis memasukkan variabel lain sebagai variabel kontrol.
Adapun variabel-variabel lain yang diduga ikut mempengaruhi produktivitas antara lain jenis lahan sawah, penggunaan pupuk, penggunaan alat dan mesin pertanian, kemitraan, skala usaha, akses ke bank, serta karakteristik petani, seperti jenis kelamin, umur, dan pendidikan.

Tabel 1. Variabel Penelitian

\begin{tabular}{cl}
\hline Variabel & \multicolumn{1}{c}{ Penjelasan } \\
\hline Produktivitas & Produksi padi dalam \\
& kualitas gabah kering \\
& giling dalam ton per \\
& hektar. \\
Sistem & Sistem tanam dibedakan \\
tanam & menurut jajar legowo dan \\
& non-jajar legowo. Sistem \\
& tanam jajar legowo terdiri \\
& atas jajar legowo 2:1, \\
& jajar legowo 4:1,jajar \\
& legowo 6:1; jajar legowo \\
& lainnya. Dalam penelitian \\
& ini, kategori referensi \\
& adalah kelompok non- \\
& jajar legowo. \\
Jenis kelamin petani \\
Jenis & terdiri dari dua kategori \\
kelamin & (laki-laki dan perempuan) \\
& di mana kelompok laki- \\
& laki sebagai kategori \\
& referensi. Petani dalam \\
& penelitian ini adalah \\
& petani utama (luas panen \\
& terluas) di setiap rumah \\
& tangga sampel. \\
Umur & Umur petani dalam tahun \\
& Penggunaan bentuk \\
& kuadrat dari variabel \\
& umur ditujukan untuk \\
& menangkap efek non- \\
& linear variabel umur \\
& terhadap produktivitas. \\
& Tingkat pendidikan petani \\
& berdasarkan pendidikan \\
& tertinggi yang ditamatkan. \\
&
\end{tabular}




\begin{tabular}{|c|c|}
\hline & $\begin{array}{l}\text { Kategori referensi adalah } \\
\text { tidak sekolah/tidak tamat } \\
\text { SD. }\end{array}$ \\
\hline Hibrida & $\begin{array}{l}\text { Varietas benih dibedakan } \\
\text { menjadi hibrida dan } \\
\text { inbrida (kategori } \\
\text { referensi). }\end{array}$ \\
\hline Jenis lahan & $\begin{array}{l}\text { Jenis lahan dibedakan } \\
\text { menjadi lahan sawah } \\
\text { irigasi dan non-irigasi } \\
\text { (kategori referensi). }\end{array}$ \\
\hline Pupuk & $\begin{array}{l}\text { Penggunaaan pupuk di } \\
\text { mana kategori referensi } \\
\text { adalah tidak } \\
\text { menggunakan pupuk. }\end{array}$ \\
\hline Alsintan & $\begin{array}{l}\text { Penggunaan alat dan } \\
\text { mesin pertanian di mana } \\
\text { kategori referensi adalah } \\
\text { tidak menggunakan alat } \\
\text { dan mesin pertanian. }\end{array}$ \\
\hline Akses bank & $\begin{array}{l}\text { Mendapatkan akses atau } \\
\text { pinjaman dari bank umum } \\
\text { atau dari Bank }\end{array}$ \\
\hline & $\begin{array}{l}\text { Perkreditan Rakyat untuk } \\
\text { usaha tani. Kategori } \\
\text { referensi tidak memiliki } \\
\text { akses bank. }\end{array}$ \\
\hline Penyuluhan & $\begin{array}{l}\text { Memperoleh } \\
\text { penyuluhan/bimbingan } \\
\text { mengenai pengelolaan } \\
\text { usaha tanaman padi. } \\
\text { Kategori referensi adalah } \\
\text { tidak memperoleh } \\
\text { penyuluhan. }\end{array}$ \\
\hline Kemitraan & $\begin{array}{l}\text { Kemitraan usaha dengan } \\
\text { badan usaha milik } \\
\text { nasional/daerah, } \\
\text { perusahaan swasta, atau } \\
\text { koperasi. Kategori } \\
\text { referensi adalah yang } \\
\text { tidak sedang melakukan } \\
\text { kemitraan usaha. }\end{array}$ \\
\hline
\end{tabular}

\section{Metode Analisis}

Metode analisis yang digunakan dalam penelitian ini adalah analisis deskriptif dan analisis inferensia. Analisis spasial digunakan dalam mengkaji sebaran implementasi sistem tanam jajar legowo untuk komoditas padi sawah menurut kabupaten/kota di Jawa Tengah.

Sementara itu, analisis inferensia digunakan untuk mengkaji dampak sistem tanam jajar legowo dan variabelvariabel lain (variabel kontrol) yang mempengaruhi produktivitas tanaman padi sawah di Jawa Tengah.

Dalam penelitian ini kami menggunakan model regresi untuk mengestimasi dampak penerapan sistem tanam jajar legowo terhadap peningkatan produktivitas tanaman padi sawah. Model regresi yang akan diestimasi dapat dituliskan sebagai berikut:

$$
\ln y_{i}=x_{i}^{\prime} \boldsymbol{\beta}+\operatorname{Jarwo}_{h} \delta+\varepsilon_{i} ; h=1, \ldots, 4
$$

dimana $y_{i}$ adalah produktivitas tanaman padi sawah di rumah tangga ke-i. Jarwo $_{k}$ adalah vektor yang memuat variabel dummy sistem tanam (jajar legowo 2:1; jajar legowo 4:1; jajar legowo 6:1; jajar legowo lainnya) dengan sistem non- jajar legowo sebagai kategori referensi. Fokus dari penelitian ini adalah mengestimasi vektor $\delta$ yang menangkap dampak kenaikan produktivitas dalam persen sebagai akibat penerapan setiap sistem tanam. Sementara itu, $x_{i}^{*}$ adalah vektor variabel yang memuat variabel-variabel lain yang dianggap dapat menjelaskan produktivitas seperti demografi petani dan karakteristik budidaya seperti yang dirinci pada Tabel 1. Vektor $x_{i}^{r}$ juga memuat variabel dummy kecamatan untuk menangkap efek spesifik wilayah (kecamatan) yang konstan untuk setiap unit observasi. $\varepsilon_{i}$ adalah kesalahan regresi 
yang diasumsikan independent and identically distributed (i.i.d).

Model penelitian diestimasi dengan Ordinary Least Square (OLS). Untuk mengatasi isu heterokedastisitas pada matriks varian-covarian residual, estimasi standard error menggunakan robust standard error. Penimbang survei (weight) juga digunakan dalam estimasi koefisien regresi.

\section{HASIL DAN PEMBAHASAN}

\section{Sebaran Impelementasi Sistem}

\section{Tanam Jajar Legowo}

Gambar 2 menyajikan sebaran implementasi sistem tanam jajar legowo untuk komoditas padi sawah di Jawa Tengah. Sebaran yang terjadi sangat beragam. Kabupaten/kota dengan tingkat implementasi sistem tanam jajar legowo relatif tinggi (lebih dari 50 persen rumah tangga usaha padi sawah di kabupaten/kota tersebut menerapkan sistem tanam jajar legowo) adalah Kabupaten Prubalingga (03), Kabupaten Banjarnegara (04), Kabupaten Grobogan (15), Kabupaten Kudus (19), Kabupaten Demak (21), Kabupaten Temanggung (23), dan Kabupaten Kendal (24). Sementara itu, kabupaten/kota dengan tingkat implementasi jajar legowo yang relatif rendah (kurang dari 10 persen rumah tangga usaha padi sawah di kabupaten/kota tersebut menerapkan sistem tanam jajar legowo) adalah Kabupaten Pekalongan (26), Kabupaten Pemalang (27), Kabupaten Tegal (29), Kota Surakarta (72), Kota Semarang (74), Kota Pekalongan (75), dan Kota Tegal (76).
Gambar 2. Sebaran Persentase Rumah Tangga Usaha Tani Padi Sawah yang Menerapkan Sistem Tanam Jajar Legowo di Jawa Tengah, 2017

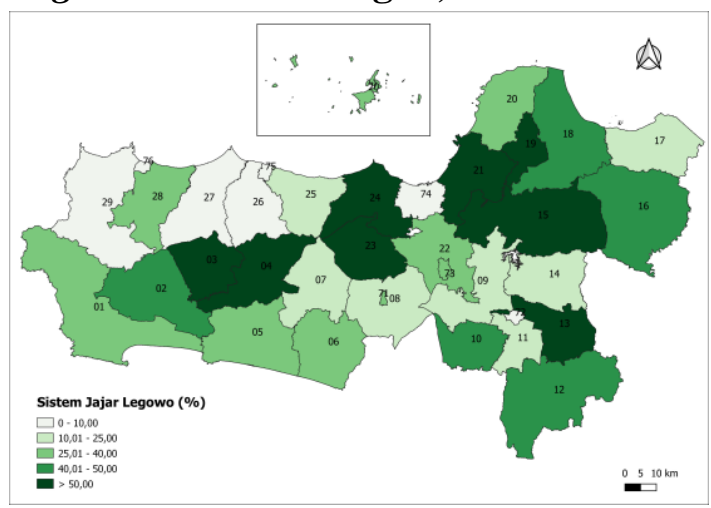

Sumber: data SOUT Tanaman Pangan 2017, BPS (diolah penulis)

Secara umum, sebagian besar petani padi sawah yang menerapkan sistem tanam jajar legowo di Jawa Tengah menggunakan pola tanam jajar legowo 4:1 (jika mengabaikan pola tanam jajar legowo lainnya), yaitu sebesar 26,86 persen. Disusul dengan pola tanam jajar legowo 6:1 dan 2:1 masing-masing sebesar 23,60 persen dan 15,69 persen (lihat Gambar 3).

Gambar 3. Persentase Rumah Tangga Usaha Tani Padi Sawah menurut Pola Tanam Jajar Legowo yang Diterapkan di Jawa Tengah, 2017

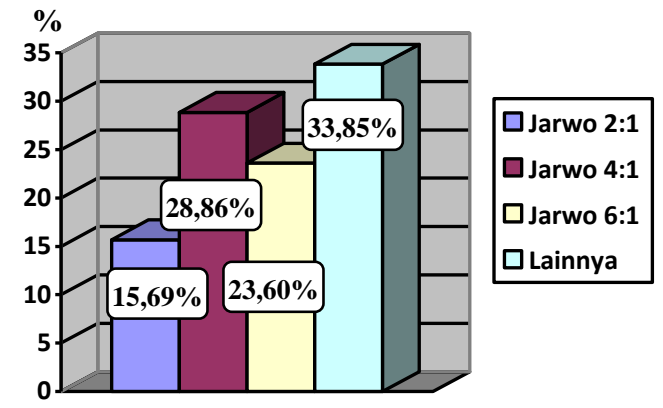

Sumber: data SOUT Tanaman Pangan 2017, BPS (diolah penulis) 
Jika dianalisis lebih mendalam sebaran yang terjadi pada tingkat kabupaten/kota menurut pola tanam jajar legowo yang diterapkan, ternyata jajar legowo 2:1 kurang diminati oleh rumah tangga usaha padi sawah di Jawa Tengah. Dapat dilihat pada Gambar 3, tingkat implementasi jajar legowo 2:1 relatif rendah di sebagian besar kabupaten/kota di Jawa Tengah (jumlah rumah tangga usaha padi sawah yang menerapkan Jajar Legowo 2:1 di kabupaten/kota tersebut kurang dari 25 persen).

Gambar 3. Sebaran Persentase Rumah Tangga Usaha Tani Padi Sawah yang Menerapkan Pola Tanam Jajar

Legowo 2:1 di Jawa Tengah, 2017

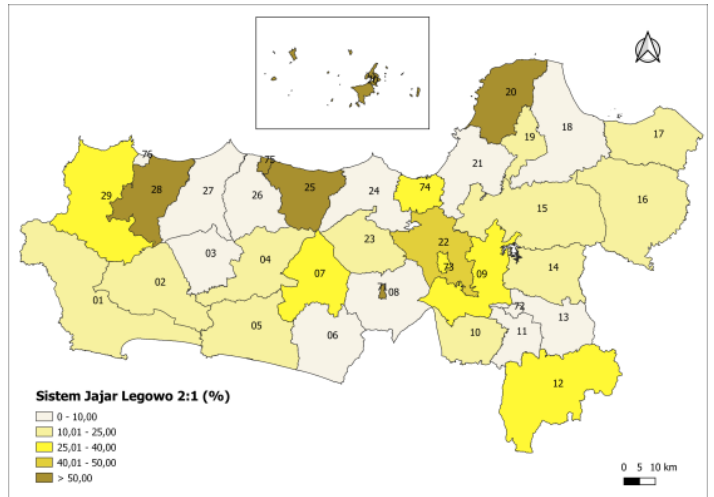

Sumber: data SOUT Tanaman Pangan 2017, BPS (diolah penulis)

Sementara itu, kabupaten/kota yang memiliki tingkat implementasi jajar legowo 2:1 lebih dari 50 persen hanya terjadi di Kabupaten Jepara (20), Kabupaten Demak (21), Kabupaten Batang (25), Kabupaten Tegal (28), dan Kota Pekalongan (75). Namun, Kabupaten Jepara dan Kota Pekalongan sebenarnya tidak memiliki partisipasi penerapan sistem tanam jajar legowo yang begitu berarti dilihat dari tingkat implementasinya yang masih di bawah 10 persen (lihat Gambar 2).
Gambar 4. Sebaran Persentase Rumah Tangga Usaha Tani Padi Sawah yang Menerapkan Pola Tanam Jajar Legowo 4:1 di Jawa Tengah, 2017

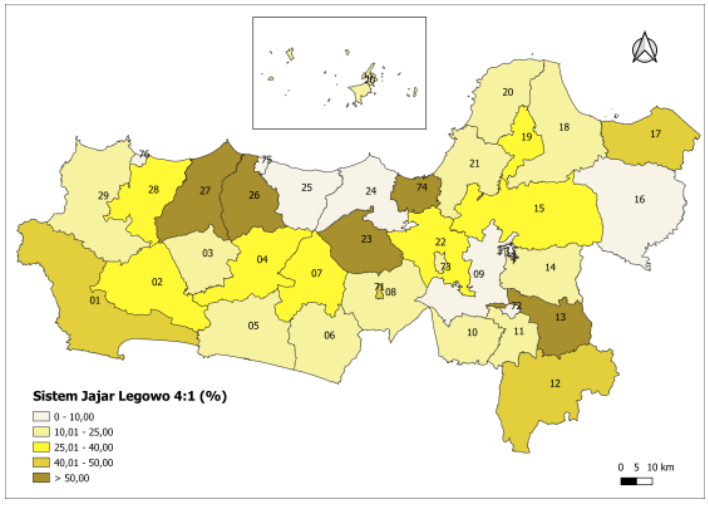

Sumber: data SOUT Tanaman Pangan 2017, BPS (diolah penulis)

Jika dibandingkan dengan sebaran persentase rumah tangga usaha tani padi sawah yang menerapkan pola tanam jajar legowo 2:1, tampaknya jajar legowo 4:1 lebih diminati di Jawa Tengah. Sebagian besar kabupaten/kota memiliki persentase rumah tangga usaha tani padi sawah diatas 25 persen. Bahkan, beberapa kabupaten/kota dengan jumlah rumah tangga usaha tani padi sawah yang menerapkan pola tanam jajar legowo 4:1 lebih dari 50 persen memiliki tingkat implementasi jajar legowo yang relatif tinggi. Kabupaten/kota dengan jumlah rumah tangga usaha tani padi sawah yang menerapkan pola tanam jajar legowo 4:1 lebih dari 50 persen yaitu Kabupaten Karanganyar (13), Kabupaten Temanggung (23). Kabupaten Pekalongan (26), Kabupaten Pemalang (27), dan Kota Semarang (74).

Gambar 5. Sebaran Persentase Rumah Tangga Usaha Tani Padi Sawah yang 
Menerapkan Pola Tanam Jajar

Legowo 6:1 di Jawa Tengah, 2017

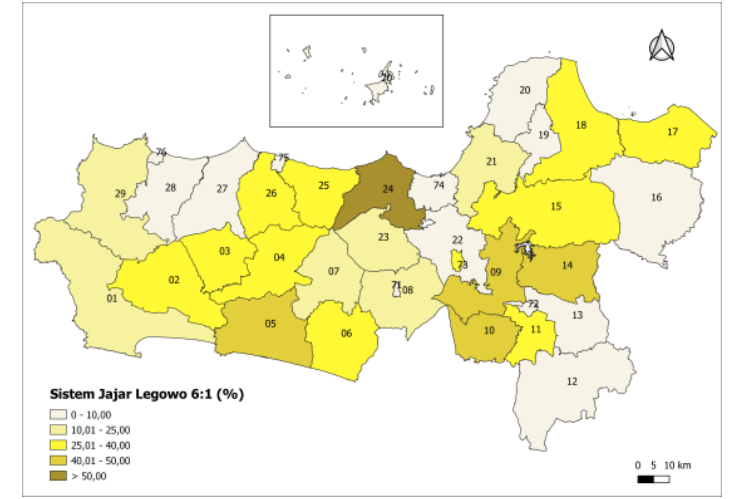

Sumber: data SOUT Tanaman Pangan

2017, BPS (diolah penulis)

Sementara itu, kabupaten/kota dengan jumlah rumah tangga usaha tani padi sawah yang menerapkan pola tanam jajar legowo 6:1 lebih dari 50 persen hanya terjadi di Kabupaten Kendal (24). Sedangkan sebagian besar kabupaten/kota lainnya memiliki persentase di bawah 40 persen.

Gambar 4. Rata-Rata Produktivitas (ku/ha) Padi Sawah menurut Pola Tanam Jajar Legowo yang Diterapkan di Jawa Tengah, 2017

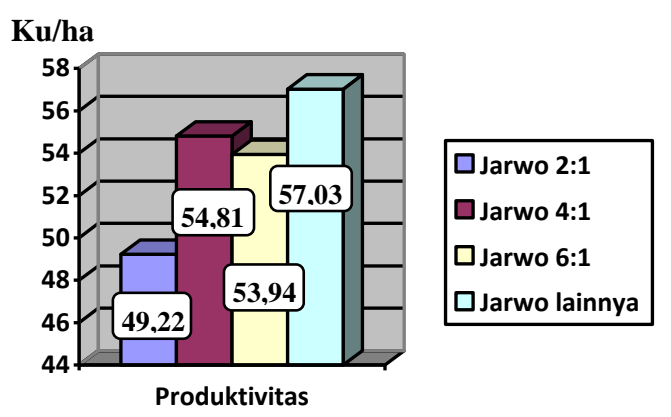

Sumber: data SOUT Tanaman Pangan 2017, BPS (diolah penulis)

Jika dilihat pada Gambar 4 yang menyajikan rata-rata produktivitas padi sawah berdasarkan pola tanam jajar legowo yang diterapkan, produktivitas tertinggi dihasilkan oleh pola tanam jajar legowo 4:1 (dengan mengabaikan produktivitas kategori jajar legowo). Produktivitas padi sawah yang dihasilkan dari penerapan sistem tanam jajar legowo 4:1 mencapai $54,81 \mathrm{ku} / \mathrm{ha}$. Kondisi ini merupakan kondisi yang menguntungkan mengingat rumah tangga usaha padi di beberapa kabupaten/kota di Jawa Tengah cenderung untuk menerapkan jajar legowo 4:1.

\section{Profil Petani Jawa Tengah}

Tabel 2 menyajikan ringkasan statistik variabel-variabel yang digunakan dalam penelitian. Sebanyak 93,32 persen petani padi sawah di Jawa Tengah berjenis kelamin laki-laki. Hal ini menunjukkan bahwa partisipasi wanita sebagai pengelola utama usaha tani padi sawah di Jawa Tengah masih rendah. Dari sisi umur dan pendidikan, karakteristik petani padi sawah di Jawa Tengah ternyata berada dalam kondisi yang kurang menguntungkan. Rata-rata umur petani padi sawah di Jawa Tengah termasuk dalam generasi tua $(55,26$ tahun) dan sebagian besar petani $(42,64$ persen) hanya menamatkan pendidikan Sekolah Dasar (SD)/sederajat dan bahkan tidak bersekolah atau tidak tamat SD (26,59 persen).

Jika dilihat menurut sistem tanam yang diterapkan, petani yang menerapkan pola tanam non-jajar legowo masih mendominasi di Jawa Tengah yaitu sebesar 67,95 persen, 32,05 persen sisanya sudah menerapkan jajar legowo dalam membudidayakan tanaman padi sawah.

Tabel 2.

Ringkasan Statistik Variabel Penelitian yang Digunakan 


\begin{tabular}{llr}
\hline No $\quad$ Variabel & $\begin{array}{c}\text { Petani Padi } \\
\text { Sawah }\end{array}$ \\
\hline \multicolumn{2}{l}{ Variabel Kontinyu (rata-rata [SD]) } \\
\hline 1. Umur (tahun) & $55,26[10,86]$ \\
\hline \multicolumn{2}{l}{ Variabel Dummy (persen) } \\
\hline 1. Jajar legowo & 32,05 \\
& a. Jarwo 2:1 & 5,03 \\
& b. Jarwo 4:1 & 8,61 \\
& c. Jarwo 6:1 & 7,56 \\
d. Jarwo lainnya & 10,85 \\
& Non-jajar legowo & 67,95 \\
2. Jenis kelamin & \\
& a. Laki-laki & 93,32 \\
b. Perempuan & 6,68
\end{tabular}

3. Pendidikan
a. Tidak sekolah
26,59
b. SD sederajat
c. SLTP sederajat
42,64
12,66
d. SLTA sederajat
13,71
e. D1/D2 sederajat
f. D3 sederajat
g. D4/S1 sederajat dan S2/S3 sederajat

4. Jenis lahan
a. Irigasi
b. Non-irigasi
75,06
24,94

5. Varietas benih
a. Hibrida
9,69
b. Inbrida
90,31

6. Pupuk
a. Menggunakan
99,96
b. Tidak menggunakan
0,04

7. Alsintan
a. Meggunakan
89,40
b. Tidak menggunakan
10,60

8. Akses bank
a. Memiliki
b. Tidak memiliki

9. Penyuluhan
a. Memperoleh
46,90
b. Tidak memperoleh

$\begin{array}{ll}\text { a. Melakukan } & 71,47 \\ \text { b. Tidak } & 28,35 \\ \text { melakukan } & \end{array}$

Sumber: data SOUT Tanaman Pangan 2017, BPS (diolah penulis)

Jika dilihat dari jenis lahan yang digunakan, sebanyak 75,06 persen petani padi sawah di Jawa Tengah menanam di lahan sawah irigasi. Sebagian besar juga menggunakan pupuk dan alat dan mesin pertanian dalam usaha tani padi sawahnya. Menariknya lagi, 71,47 persen petani padi sawah di Jawa Tengah melakukan kemitraan menunjukkan bahwa sebagian besar petani di Jawa Tengah sadar akan pentingnya kemitraan dalam meningkatkan produktivitas hasil panen dan pendapatan petani. Namun, sayangnya varietas benih masih terkonsentrasi pada varietas inbrida (90,31 persen). Di samping itu, sebagian besar petani padi sawah di Jawa Tengah (97,22 persen) ternyata tidak memiliki akses bank atau tidak melakukan pinjaman ke bank.

\section{Dampak Jajar Legowo dan Variabel Lainnya dalam Peningkatan Produktivitas}

Hasil estimasi model regresi yang disajikan pada Tabel 3 memperlihatkan bahwa sebagain besar variabel yang diikutkan dalam estimasi model signifikan secara statistik pada tingkat signifikansi 5 persen. Tanda dan magnitude estimasi koefisien regresi secara umum juga sesuai dengan yang diharapkan.

10. Kemitraan 
Hasil estimasi mengkonfirmasi bahwa sistem tanam jajar legowo berdampak signifikan dalam meningkatkan produktivitas tanaman padi sawah di Provinsi Jawa Tengah. Secara rata-rata, produktivitas tanaman padi sawah dengan sistem tanam jajar legowo lebih tinggi sekitar 9 persen dibanding tanaman padi yang dibudidayakan bukan dengan sistem tanam jajar legowo. Teknik jajar legowo yang memberikan produktivitas tertinggi adalah jajar legowo lainnya, yakni sekitar 16 persen lebih tinggi dari produktivitas padi dengan sistem non-jajar legowo. Menariknya, meskipun memiliki arah yang positif, jajar legowo 2:1 ternyata tidak memberikan pengaruh yang signifikan dalam peningkatan produktivitas. Hal ini perlu dicermati secara hati-hati mengingat terdapat kemungkinan bahwa teknik jajar legowo yang dipraktekkan oleh petani belum sesuai dengan standar yang telah ditetapkan.

Hasil estimasi juga menunjukkan sejumlah temuan menarik lainnya. Terdapat kecenderungan ketimpangan produktivitas antara petani perempuan dan laki-laki meskipun tidak signifikan secara statistik. Dalam hal ini, produktivitas petani laki-laki sekitar 2 persen lebih tinggi dibanding petani perempuan. Hal ini boleh jadi disebabkan oleh perbedaan kapasitas petani perempuan dan laki-laki dalam menjalankan budidaya tanaman padi sawah. Arah estimasi ini sejalan dengan penelitian Tran, dkk (2018) yang menemukan bahwa produktivitas padi yang dihasilkan oleh rumah tangga dengan kepala rumah tangga laki-laki akan lebih tinggi sebesar 10,3 persen jika dibandingkan dengan produktivitas padi yang dihasilkan oleh rumah tangga dengan kepala rumah tangga perempuan.
Pertambahan umur petani secara umum cenderung berdampak negatif terhadap produktivitas tetapi tidak signifikan secara statistik pada tingkat signifikansi 5 persen. Hal ini nampaknya menunjukkan bahwa dampak kenaikan umur terkompensasi oleh peningkatan pengalaman seiring bertambahnya umur.

Dampak pendidikan positif dan signifikan terhadap peningkatan produktivitas. Hal ini mengkonfirmasi bahwa pendidikan dapat meningkatkan kapasitas petani dalam menyerap introduksi teknologi untuk meningkatkan produktivitas tanaman padi. Secara umum, semakin tinggi pendidikan petani, semakin tinggi produktivitas tanaman padi yang dibudidayakan. Paltasingh dan Goyari (2018) menemukan bahwa tingkat pendidikan minimum petani secara signifikan mempengaruhi pengadopsian varietas padi modern oleh petani dan mendorong dalam peningkatan produktivitas.

Penggunaan variates unggul, khususnya benih padi hibrida, juga berdampak positif dan signifikan terhadap peningkatan produktivitas. Hasil estimasi memperlihatkan bahwa padi hibrida memberikan produktivitas yang lebih tinggi sekitar 3 persen dari padi nonhibrida. Sayangnya, sebagaimana ditunjukkan pada Tabel 2 preferensi petani Jawa Tengah untuk membudidayakan tanaman padi hibrida masih relatif rendah, yakni hanya sebesar 9,69 persen. Hal yang sama juga berlaku pada penggunaan pupuk yang dapat meningkatkan produktivitas tanaman padi sebesar 15 persen dan penggunaan alat dan mesin pertanian sebesar 17 persen. Temuan ini menunjukan pentingnya modernisasi teknik budidaya dalam meningkatkan produktivitas tanaman padi. 
Menarik untuk dicermati bahwa petani yang memperoleh penyuluhan juga memiliki produktivitas tanaman padi yang lebih tinggi dibanding dengan petani yang tidak memperoleh penyuluhan. Dampak penyuluhan yang masih kecil, sekitar 2 persen, dapat disebabkan oleh efektivitas penyuluhan yang diberikan dalam meningkatkan produktivitas tanaman padi di Jawa Tengah belum maksimal. Selain itu, penyuluhan dalam penelitian ini bersifat umum tidak hanya spesifik untuk teknik budidaya. Boleh jadi petani memperoleh penyuluhan tapi tidak terkait dengan teknik budidaya.

Kemitraan ternyata memiliki pengaruh positif dan signifikan terhadap produktivitas padi sawah di Jawa Tengah. Petani padi sawah yang melakukan kemitraan memiliki produktivitas yang lebih tinggi sebesar 11 persen jika dibandingkan dengan petani padi sawah yang tidak melakukan kemitraan. Jika melihat kembali pada Tabel 2, sebagian besar petani padi sawah di Jawa Tengah ternyata sadar akan pentingnya melakukan kemitraan. Kemitraan yang dilakukan dapat dengan BUMN, BUMD, perusahaan swasta, atau pun koperasi.

Tabel 3.

Estimasi persamaan regresi

\begin{tabular}{lc}
\hline & OLS \\
\hline Jarwo 2:1 & 0,0326 \\
& $(0,0220)$ \\
Jarwo 4:1 & $0,0903^{* * *}$ \\
& $(0,0163)$ \\
Jarwo 6:1 & $0,0911^{* * *}$ \\
& $(0,0173)$ \\
Jarwo lainnya & $0,1616^{* * *}$ \\
& $(0,0140)$ \\
Perempuan & $-0,0210$ \\
& $(0,0183)$ \\
Umur & 0,0022 \\
& $(0,0031)$ \\
Umur $^{2}$ & $-0,0033$
\end{tabular}

\begin{tabular}{|c|c|}
\hline & OLS \\
\hline & $(0,0028)$ \\
\hline \multirow[t]{2}{*}{$\mathrm{SD}$} & $0,0296 * *$ \\
\hline & $(0,0123)$ \\
\hline \multirow[t]{2}{*}{ SMP } & $0,0456 * * *$ \\
\hline & $(0,0176)$ \\
\hline \multirow[t]{2}{*}{ SMA } & $0,0728 * * *$ \\
\hline & $(0,0172)$ \\
\hline \multirow[t]{2}{*}{$\mathrm{D} 1 / \mathrm{D} 2$} & 0,0404 \\
\hline & $(0,0812)$ \\
\hline \multirow[t]{2}{*}{ D3 } & $0,1768 * * *$ \\
\hline & $(0,0388)$ \\
\hline \multirow[t]{2}{*}{ Universitas } & 0,0106 \\
\hline & $(0,0464)$ \\
\hline \multirow[t]{2}{*}{ Hibrida } & $0,0332 * *$ \\
\hline & $(0,0137)$ \\
\hline \multirow[t]{2}{*}{ Irigasi } & $0,0628 * * *$ \\
\hline & $(0,0109)$ \\
\hline \multirow[t]{2}{*}{ Pupuk } & $0,1540 * * *$ \\
\hline & $(0,0344)$ \\
\hline \multirow[t]{2}{*}{ Alsintan } & $0,1739 * * *$ \\
\hline & $(0,0166)$ \\
\hline \multirow[t]{2}{*}{ Akses bank } & $0,1082 * * *$ \\
\hline & $(0,0248)$ \\
\hline \multirow[t]{2}{*}{ Penyuluhan } & $0.0234 * * *$ \\
\hline & $(0.0105)$ \\
\hline \multirow[t]{2}{*}{ Kemitraan } & $0,1152 * *$ \\
\hline & $(0,0382)$ \\
\hline \multicolumn{2}{|c|}{ Dummy kecamatan - } \\
\hline \multicolumn{2}{|c|}{$\mathrm{R}^{2}=0,1346 ;$ Jumlah obs $=11.498$} \\
\hline \multicolumn{2}{|c|}{$\begin{array}{l}\text { Catatan: } * * * \text { signifikan pada } \alpha=1 \% ; * * \\
\text { signifikan pada } \alpha=5 \% ; * \text { signifikan pada } \alpha= \\
10 \% \text {. Penimbang digunakan dalam estimasi. }\end{array}$} \\
\hline
\end{tabular}

Hasil estimasi juga mengkonfirmasi peran penting akses petani terhadap sektor finansial. Petani yang memiliki akses untuk memperoleh permodalan dari bank secara rata-rata memiliki produktivitas yang lebih tinggi sekitar 11 persen dibanding mereka yang tidak memiliki akses pinjaman dari bank. Hal ini dapat dijelaskan bahwa petani yang memiliki akses pemodalan dari bank cenderung memiliki kesempatan untuk melakukan teknik budidaya yang dapat menunjang peningkatan produktivitas seperti penggunaan pupuk, benih unggul, penggunaan alsintan, dan pengendalian 
serangan hama dan organisme pengganggu tumbuhan (OPT).

\section{SIMPULAN}

Penelitian ini bertujuan menganalisis sebaran implementasi sistem tanam jajar logowo dalam budidaya tanaman padi sawah di Provinsi Jawa Tengah serta dampaknya terhadap peningkatan produktivitas tanaman padi. Dampak variabel lain terhadap produktivitas juga dianalisis dalam penelitian ini. Hasil SOUT 2017 memperlihatkan bahwa meski sistem tanam jajar logowo menjanjikan produktivitas tanaman padi yang lebih tinggi, proporsi rumah tangga tani yang menerapkan teknik ini masih relatif kecil, yakni hanya sebesar 32,05 persen dari total rumah tangga usaha tanaman padi sawah di Provinsi Jawa Tengah. Kabupaten/kota dengan tingkat implementasi sistem tanam Jajar Legowo relatif tinggi (sebagian besar rumah tangga usaha tanaman padi sawah menerapkan sistem tanam Jajar Legowo) terkonsentrasi di Kabupaten Prubalingga, Banjarnegara, Grobogan, Kudus, Demak, Temanggung, dan Kendal.

Hasil penelitian ini mengkonfirmasi bahwa sistem tanam jajar legowo berdampak signifikan terhadap peningkatan produktivitas tanaman padi sawah di Provinsi Jawa Tengah. Karena itu, meningkatkan partisipasi petani dalam implementasi sistem tanam ini dapat menjadi salah upaya yang dapat ditempuh untuk meningkatkan produksi padi/beras secara signfikan di Provinsi Jawa Tengah. Selain itu, meningkatkan kapasitas petani, penggunaan benih unggul dan alsintan, dan meningkatkan akses petani untuk mendapatkan pinjaman modal dari bank juga berdampak signifikan dalam meningkatkan produktivitas tanaman padi sawah yang dibudidayakan oleh petani.

\section{DAFTAR PUSTAKA}

Badan Pusat Statistik. (2017). Hasil Survei Struktur Ongkos Usaha Tanaman Padi Provinsi Jawa Tengah 2017. DKI Jakarta: Badan Pusat Statistik.

Badan Pusat Statistik. (2018). Berita Resmi Statistik Luas Panen dan Produksi Padi di Indonesia 2018, No.83/10/Th. XXI, 24 Oktober 2018. Diunduh dari https://www.bps.go.id/pressrelease.html Tanggal 5 Februari 2019

Direktorat Jenderal Tanaman Pangan, Kementerian Pertanian. (2016). Petunjuk Teknis Teknologi Tanam Jajar Legowo Tahun 2016. DKI Jakarta: Dirjen Tanaman Pangan.

Ikhwani, Gagad, R.P., Eman, P., \& A.K. Makarim . (2013). Peningkatan Produktivitas Padi Melalui Penerapan Jarak Tanam Jajar Legowo. Iptek Tanaman Pangan Vol 8 No.2. 7279 .

Sembiring, H. (2008). Kebijakan Penelitian dan Rangkuman Hasil Penelitian BB Padi dalam Mendukung Peningkatan Produksi Beras Nasional. Apresiasi Hasil Penelitian Padi Menunjang

Sembiring, H. (2008). Kebijakan Penelitian dan Rangkuman Hasil Penelitian BB Padi dalam Mendukung Peningkatan Produksi Beras Nasional. Dalam: Prosiding Seminar Apresiasi Hasil Penelitian Padi Menunjang P2BN. Balai Besar Penelitian Tanaman Padi. 39-59. 
Susilastuti, D., Aditiameri, \& U. Buchori. (2018). The Effect of Jajar Legowo Planting System on Ciherang Paddy Variaties. Agritropica: Journal of Agricultural Science. 11 (1): $1-8$.

Witjaksono, Julian. (2018). Kajian Sistem Tanam Jajar Legowo untuk Peningkatan Produktivitas Tanaman Padi di Sulawesi Tenggara. Jurnal PANGAN Vol 27 No.1 April 2018. 1-8.

Tran, Thi Kieu Van, E. Elahi, L. Zhan, V.H. Bui, Q.T. Pham, T.D. Tran, T.L.Ta, \& M. Hassan, (2018). Gender Gap in Rice Productivity: Evidence from Vietnam, International Journal of Social Economics. Diakses dari https://doi.org/10.1108/IJSE$12-2017-0623$

Paltasingh, K.R., \& P. Goyari. (2018). Impact of Farmer Education on Farm Productivity under Varying Technologies: Case of Paddy Growers in India. Agricultural and Food Economics 6:7. Diakses dari https://doi.org/10.1186/s40100-018-0101-9 